\title{
Drafting Assistance On Traditional Jamu UMKM
}

\author{
Wahyuning Murniati \\ Departement of Accounting, STIE Widya Gama Lumajang, Indonesia \\ Email: wahyuning123@gmail.com
}

\begin{tabular}{lll}
\hline Submission : & Review : & Publication : \\
$4^{\text {st }}$ April 2020 & $13^{\text {th }}$ June 2020 & $28^{\text {th }}$ Augustu 2020 \\
\hline
\end{tabular}

\begin{abstract}
Abstrak
Patent Drafting is a method for preparing patent documents. As it is known, UMKM Jamu is engaged in the health sector by producing traditional herbal medicine which is believed to be effective in preventing the growth of cancer cells and various other diseases. UMKM located in Wonorejo Village, Lumajang Regency, need patent drafting assistance for the preparation of patent documents. Therefore, this assistance is carried out with the aim of providing understanding to the UMKM Jamu Ibuk producers regarding patents. The output of this activity is a patent document ready to register. With this activity, it is hoped that it can provide thoughts on the importance of protecting Intellectual Property for MSMEs and the wider community.
\end{abstract}

\section{Keywords: UMKM, Intellectual Property, Patents}

\section{INTRODUCTION}

Many entrepreneurs think more about how to make their business grow. This in turn makes entrepreneurs forget about things that are no less important, namely the role of patents for products. Patent rights have an important role for business development. On the Ministry of Industry's website kemenperin.go.id, it is noted that the number of patent applicants has increased from year to year. In 2013, there were 7,450 registrants. A year later, there were 8,023 registrants. The growth rate up to 2015 is around 800 registrants. In comparison, the growth in the number of patent registrations in the last five years in China reached 122 thousand. In 2014, patent applicants in China reached 928,177. In South Korea, the growth rate reached 40 thousand registrants with 210,252 registrants in 2014. Seeing this, the CEO of PT Makmur Sukses Untung Ari Sudradjat also applied for a patent for the product he owned. "We are currently registering patents for our technology products," Ari said recently as quoted by Detik. According to Ari, patent ownership is important to develop the products his party invented to seize the local market.

As is well known, the herbal and traditional medicine industry this year is estimated to grow $10 \%$ with a turnover of IDR 17 trillion. This is the same as said by Charles Saerang, Chairman of the Board of Trustees of the GP Jamu. "The national herbal and traditional medicine industry is increasing by an average of 5\% per year. In 2017, it will generate a turnover of around Rp. 15 trillion," said Charles Saerang, Chairman of the GP Jamu Advisory Board, Monday (20/8). Overall, he continued, the national drug industry was able to absorb a workforce of 15 million people. About 3 million people are absorbed in the herbal medicine industry which functions as medicine. Meanwhile, around 12 million people are absorbed in the food, beverage, cosmetic, spa and aromatherapy herbal industry. 
Patent Drafting is one method of preparing patent registration documents. There are several rules and ways of writing in preparing a patent draft. The limited knowledge related to the patent draft is the background for this activity at UMKM Jamu Ibuk. In general, this activity is a continuation of previous activities, where MSMEs received material related to the importance of protecting intellectual property. Therefore, this activity aims to provide assistance regarding the preparation of patent drafts from UMKM Jamu Ibuk.

The problem experienced by Jamu Ibuk MSMEs in this case is regarding the protection of formulas from traditional herbal medicine products. In this case, it is necessary to protect the intellectual property related to the herbal medicine produced by UMKM. Patents are an option in the protection of the Jamu Ibuk formula. However, in practice, the producers do not have sufficient knowledge regarding intellectual property protection. Therefore, this assistance is carried out with the objective of an output in the form of a draft patent which will then be used for the patent registration process in accordance with the applicable regulations.

Based on the problems described in the previous chapter, the solution will be focused on assisting patent drafting for traditional herbal formulas produced by partners. The expected output of this activity is a patent draft in accordance with the traditional herbal formula produced by the partner. This activity is guided through the related patent registration process. It is hoped that this will increase the awareness of partners in particular and other MSMEs in general in Lumajang Regency

\section{IMPLEMENTATION METHODS}

Method in this activity uses Action research. Action research is carried out jointly by at least two people, namely between researchers and participants or clients from academia or society. Therefore, the objectives to be achieved from an action research will be achieved and will end not only in certain organizational situations, but will continue to be developed in the form of applications or theories then the results will be published to the public for research purposes (Madya, 2006).

\section{RESULTS AND DISCUSSION}

The following is the flow of community service activities carried out at UMKM Jamu Ibuk Wonorejo, Lumajang Regency. The description of the flow above is as follows: 1 . The preparation stage is the stage with the aim of preparing the activities in order to achieve the goals that have been previously made. The systematic of this stage is given in Table 3.1 where all the stages are interrelated and end with the preparation of proposals or proposals for activities. 2. The implementation stage is the core stage of this community service activity. At this stage, it contains the delivery of material that is relevant to the target of the activity in order to solve the problems raised. 3 . The reporting stage is the final stage of this activity where activity reports are compiled which can then be used or utilized by others.

As we know, Intellectual Property Rights or abbreviated as "IPR" are rights arising from the results of the thinking of the human brain that produces a product or process that is useful to humans. In general, it can be said that the objects regulated in IPR are works that arise or are born due to human intellectual abilities. Therefore, some argue that these rights are classified into intangible or intangible goods. The analogy is if these ideas come out of the human mind and incarnate in a creation of literature, science, etc., then they become tangible objects and can become a source of profit (Samsudin, 2016). 
We often hear the term "patent" widely used by the wider community; and even often misunderstood as the equivalent of the term "intellectual property rights" itself. In fact, however, patents are only one of the many forms of IPR protection. Patents are IPR protection for intellectual works of a technological nature, also known as inventions, and contain technical solutions / solutions to problems that exist in pre-existing technology. For example, the tiny nails invented by Levi Strauss to be attached to the ends of jeans pockets, for example, which were awarded a patent in the United States in 1873, contained a technical solution to the problem of easy removal / tearing of the pocket stitches made of denim at that time, considering usage. outdoor with a high enough intensity. Patent invention can be in the form of product or process. For example, combustion in a motorized vehicle engine which aims to produce exhaust emissions that are more environmentally friendly.

Both the method and process how the combustion is carried out, and the engine that applies the combustion method and process, can both be patented as process patents and product patents, respectively. In general, the methods for filing a patent application are as follows; 1. Submit an application to the office of the Directorate General of Intellectual Property (DJKI) in writing in Indonesian by filling out the application form provided and typed in. 2. Applicant must attach: a. special power of attorney, if the application is submitted through a registered KI consultant as the attorney; b. letter of transfer of rights, if the application is submitted by another party who is not the inventor; c. The description of the Patent application is made in duplicate and includes: - the title of the invention, made in capital letters and not underlined; • the technical field of the invention, containing in general terms where this invention is included in the said technical field by stating its specificity; background of the invention, it is necessary to state the existing technology which is relevant to the invention; - summary of the invention, containing the technical characteristics of the principal of the invention disclosed in the claim; - a brief description of the image (if included), contains a brief description of the image; - a complete description of the invention, which is a complete disclosure of the invention, nothing should be left behind or not disclosed; - claims (made on a separate page), contain the subject matter of the invention and may not contain pictures or graphs but may contain tables of mathematical formulas or chemical reactions; - abstract (made on a separate page), containing a summary of a complete description of the invention in no more than 200 words. d. pictures, if any, are made in 2 copies: only contain signs, symbols, letters, numbers, charts, or diagrams explaining the parts of the invention, but no explanatory words are allowed; e. Original priority evidence, and a translation of the front page in Indonesian in duplicate, if submitted with priority rights; $\mathrm{f}$. a translation of the description of the invention in English, if the invention is originally in a foreign language other than English; g. proof of payment of patent application fee; 3 . Descriptions, claims, abstracts and drawings as referred to in point 2 letters $\mathrm{c}$ and $\mathrm{d}$ are written as follows: 4. each sheet of paper has only one face that may be used for writing and drawing; 5. Descriptions, claims and abstracts typed in HVS paper or the like and separately, A4 size, minimum weight 80 grams with the following limits:

upper limit: $2 \mathrm{~cm}$, lower limit: $2 \mathrm{~cm}$, left limit: $2.5 \mathrm{~cm}$, right limit: $2 \mathrm{~cm}$, 6 . The A4 paper must be white, not even glossy and should be used by placing its short sides at the top and bottom (unless it is used for drawings); 7. each sheet of description, claims and drawings shall be numbered in Arabic numerals at the top center and not on the boundary as referred to in point 3 letter $b(1)$;

8. every five lines of typing the description and claim line, must be given a line number and each new page is the beginning (beginning) of the number and placed to the left of the description or claim and not within the boundary as referred to in point 3 letter b (3); 9 . 
typing must be done using black ink (toner), with a space of 1.5 and upright letters with a minimum letter height of $0.21 \mathrm{~cm} ; 10$. Signs with lines, chemical formulas, and certain signs can be written by hand; 11.Images must use black Chinese ink on A4 size white drawing paper with a minimum weight of 100 grams of matte with the following limits: upper limit: $2.5 \mathrm{~cm}$, lower limit: $1 \mathrm{~cm}$, left limit: $2.5 \mathrm{~cm}$, right limit: $1.5 \mathrm{~cm}$. 12. All Patent documents filed must be in complete sheets of paper, not torn, folded, damaged or an image attached; 13. Every term used in the description, claim, abstract and drawings must be consistent with one another.

The initial activity in this community service is a pre-survey activity, with the following activity stages; (a) Determining problems to be resolved, (b) Determining activity objectives, (c) Determining activity objectives, and (d) Formulating activity proposals. Activity (a) is carried out by formulating the UMKM Jamu Ibuk problem by conducting interviews followed by a case study. The problem arises when there are many other manufacturers with traditional herbal medicine products that have started to emerge since Jamu Ibuk was marketed online. This concern is reasonable because manufacturers do not legally protect their products. So it does not rule out that the Jamu Ibuk product will be copied by other manufacturers. Based on these problems, activity (b) is carried out by formulating the objectives of this community service activity. The initial goal is the producers' understanding of the importance of protection of Intellectual Property as well as the benefits if IPR is obtained by MSMEs. After the goals and objectives are clear, an activity proposal is made which is then used as a description of the activities for the producer and the campus.

Implementation activities are carried out in steps, among others; (a) Preparing activity materials to be given, (b) Determining solutions to the specified problems, (c) Determining activity outputs, and (d) Implementing community service activities. The material was prepared in accordance with the goals and objectives of this activity. In addition, solutions are given related to problems experienced by UMKM Jamu Ibuk. This activity was attended by the producers of Jamu Ibuk which then held a discussion session so that the goals and objectives were achieved in this activity. The last series in this community service is the reporting of the results of all activities. However, in practice patent drafting takes longer. Therefore, this assistance will continue until the patent draft has been completed in accordance with existing regulations.

\section{CONCLUSION}

This activity led to the conclusion that patents as an intellectual property must be protected. In addition, the protection of UMKM products can be carried out by registering their IPR to maintain the level of originality of the UMKM products in facing ASEAN free competition. This of course aims to increase the marketing activities of traditional herbal medicine products produced by Jamu Ibuk UMKM. Based on the above conclusions, the same activities should be carried out on other MSMEs, not only in the field of traditional herbal medicine but also for other products.

\section{REFERENCES}

Asti, W. A. H. (2016). Perlindungan Produk Usaha Mikro Kecil Dan Menengah Terkait Hak Kekayaan Intelektual Dalam Menghadapi Masyarakat Ekonomi Asean. 
Incubator. (2018). Kontribusi UMKM Dalam Roda Perekonomian Indonesia.

Samsudin, D. (2016). Hak Kekayaan Intelektual Dan Manfaatnya Bagi Lembaga Litbang. Direktorat Jenderal Kekayaan Intelektual Kementerian Hukum Dan Hak Asasi Manusia.

Susanty, A. P. (2018). Perlindungan Hukum Terhadap Kelangsungan Usaha Mikro, Kecil, dan Menengah Atas Pemberlakuan Masyarakat Ekonomi Asean. Jurnal Hukum Respublica. https://doi.org/10.31849/respublica.v16i2.1443 